\title{
OBITUARIES
}

\section{Prof. T. R. C. Fox}

Thrence Robert Corelli Fox, the first Shell professor of chemical engineering in the University of Cambridge, died in London on October 5 at the age of fifty. He was born on May 2, 1912, the only son of the late C. Fox, and was educated at the Regent Street Polytechnic Secondary School from where he won a minor scholarship to Jesus College, Cambridge, which he entered in 1930. At Cambridge Fox read for the Mechanical Sciences Tripos and throughout the course swept all before him. $\mathrm{He}$ obtained first-class honours in the Tripos of 1933 with the Rex Moir Prize, which is awarded to the candidate placed top of the list, and distinctions in theory of structures and in aeronautics. He received in addition three University prizes for the best performance in thermodynamics, in aeronautics and in structures.

On going down from Cambridge he joined Imperial Chemical Industries, Ltd., as a technical assistant and had four years of practical experience at Billing. ham before returning to Cambridge as a University demonstrator in engineering in 1937. He was elected a Fellow of King's College in 1941 and was promoted University lecturer in 1945. As one of his grateful pupils stated in The Times of October 9, Fox, while being a good and clear lecturer, was probably at his best as a college supervisor; in this capacity he gave invaluable service to King's. In the years immediately after the War he played a prominent part in the Department of Engineering in the re-organization of the courses which led to the division of the Tripos into two parts in 1947 .

In 1946, Cambridge received a great benefaction from the Shell Group which enabled the University to establish a department of chemical engineering and Fox was elected to the new Shell professorship. At this time chemical engineering was a somewhat neglected subject in British universities. The number of students was small, and scientifically the subject was probably well behind its American counterpart. Fox spent a year visiting American universities to see how the subject was treated there, and on his return drafted a syllabus which combined the best of what he had seen with certain additional features which were the product of the Cambridge engineering tradition and of his own meticulous and penetrating mind. When he turned his attention for the first time to ehemical thermodynamies, for example, his scrutiny went far deeper than that of most physical chemists. The staff, which he assembled from various disciplines, after recovering from the realization that they still had much to learn, came to share Fox's rigorous approach to the subject. The result has been that chemical engineering enjoys the undisputed status of an academic discipline not only at Cambridge but also at a dozen other universities; for Fox's doctrines have spread widely, and five members of the Cambridge staff have left to become professors elsewhere. The fact that the subject has shaken off its dubious associations with the oldfashioned chemical technology and that it has become the antithesis of an 'easy option' is due as much to Fox as to anyone.
Fox also carried the main burden of housing and equipping the new department. He first secured a temporary site where he built a small but efficient laboratory in huts. No sooner was this completed than he began to plan a more permanent laboratory. On this he lavished every care and, though his meticulous attention to the master-plan and to every detail was probably a trial to both the architect and contractor, the building in Pembroke Street to which the Department moved in 1959 stands as a memorial to his far-sightedness.

The burden of administering a university science department to-day can be heavy, but it is small compared with the labour and anxiety of creating one. Fox, who was a gentle and modest man, exhausted himself during twelve years of effort and was forced by ill-health to resign his chair in 1959. He returned as a University lecturer to the Department of Engineering to which he had earlier given devoted service.

Fox, in spite of his outstanding ability, was devoid of any personal ambition to make a name for himself as a public figure, a writer or research worker. $\mathrm{H}_{\Theta}$ devoted himself single-mindedly to the well-being and efficiency of his department, and many of his former colleagues and pupils will remember gratefully the humanity with which he did so. JoHN BAKER

\section{Mr. Walter Buddin}

Walter Buddin died on August 14 at Reading, after a short illness. His death must have come as a considerable shock to many friends who had talked with him less than a month earlier at a meeting of the British Mycological Society in Harpenden. On that occasion, he had appeared in good health, and was certainly in his usual cheerful spirits. For many years, no meeting of the Society had seemed complete without him, and there was no member whose loss could have caused a greater gap.

Born on November 5, 1890, Walter Buddin eventually proceeded to Sidney Sussex College, Cambridge, and studied in the School of Agriculture. After taking his B.A. degree (he later took the M.A.), he was awarded a Board of Agriculture Research Scholarship in 1912, and went with it to Rothamsted, where he took part in research on partial sterilization of soil under the direction of Sir John Russell, and later visited the United. States. During the First World War, he served with the R.A.M.C., spending part of his time in Egypt, where he contracted para. typhoid fever-a misfortune that may have been responsible for impaired health in later life. In 1919, he became a Ministry of Agriculture research exhibitioner at the Cheshunt Experimental Station, where he collaborated with the director, Dr. W. F. Bewley, in studying contamination of glasshouse water supplies by the spores of plant-pathogenic fungi; their joint paper on this subject attracted wide attention and is still quoted. During 1921-46, Buddin held the post of economic mycologist to the Southern Advisory Province and was attached to the University of Reading. In 1946 he transferred to the analogous position in the newly formed National Agricultural Advisory Service and continued in the 
new laboratory at Reading until his retirement in 1956.

During his thirty-five years in the agricultural advisory service, Buddin somehow made time to carry through and publish a not inconsiderable volume of fundamental research on fungal diseases of crops and ornamental plants, in addition to the more ad hoc investigations on disease control that arose out of his work as an adviser. Most of his more important work was published in collaboration with Miss E. M. Wakefield. Best known is their joint work on the violet root rot disease, in the course of which they established that Helicobasidium purpureum was the perfect state of the pathogen, until then known only as a sterile mycelium (Rhizoctonia crocorum). Although this discovery attracted widespread attention, equal credit is due to Buddin and Wakefield for their preliminary study of the biology of $R$. crocorum in culture. They were among the first mycologists to isolate this fungus in pure cultureat that time a considerable technical feat. Twenty years later, when I followed in their footsteps, I was able to confirm their observations and to admire the thoroughness and mycological finesse of their work.

Gifted as he was in his capacity as a research worker, yet as an agricultural adviser Buddin had, in my opinion, no equal. He combined an immense zest for his job with an uncanny knack of being able to enter into the minds of farmer and research worker simultaneously, so that he was the ideal interpreter of one to the other. Above all this, he had an extraordinary flair for seeing how research findings could be put into practice, though fow people can have realized just how great was his contribution in this respect, because Buddin was a most generous man and seemed to care little about recognition for himself. Many young men besides me had this generous help from him, were made to foel that their research work was worth doirig and were taught by example rather than by precept that one had to become an expert in general crop husbandry before one could become useful as a plant pathologist. A large part of Buddin's success with farmers was due to his kindly and never-flagging interest in the affairs of other people and to a most retentive memory. In the houses of his hosts, he was able to ask the most direct and personal questions without causing the slightest offence; a few years later, this information would be deployed to great effect in inquiries about the well-being of the family concerned.

Buddin's outstanding services to science and agriculture were widely recognized. He was elected an honorary member of the British Mycological Society in 1954 and of the Association of Applied Biologists in 1959 , and was the first British biologist to hold both these distinctions. His association with the British Mycological Society was a particularly close one; at one time or another he held most of the offices of the Society, though he characteristicully refused to be nominated for the presidency. His final service to the Society was as troasurer during 1947-61, during which time the Council received much wise advice, and the most tedious business was invariably enlivened by Buddin's pithy comments. Wit and philosopher though he was, it was perhaps Buddin's infectious enjoyment of his life and work that most endeared him to his friends and helped them to do the same. To have been helped by, and to have exjoyed the friendship of, such a man will be the treasured recollection of many of us.

S. D. GarretT

\section{Prof. V. N. Beklemishev}

Prow. Vladimir Nikolaievitch Beklemishev, head of the Division of Entomology of the Martsinovsky Institute of Medical Parasitology and Tropical Medicine of the U.S.S.R. Ministry of Health, member of the U.S.S.R. Academy of Medical Sciences, died in Moscow on September 4 at the age of seventytwo years.

Prof. Beklemishev's death will leave in the field of medical entomology a gap that will not be easy to fill. His contribution to basic science was immense, linked with his interest in applied research and particularly related to problems of public health and to malaria eradication. Thirty years ago, while still on the staff of the University of Perm, Prof. Beklemishev became interested in the biology of impounded waters giving rise to large-scale breeding of Anopheles. This work led to the study of epidemiology of malaria, to which Prof. Beklemishev had devoted most of his work since 1932, when he was appointed head of the Entomology Division of the Malaria Institute in Moscow (now the Martsinovsky Institute of Medical Parasitology and Tropical Medicine).

In his new post, Prof. Beklemishev devoted all his knowledge, energy and experience to the organization of country-wide control of malaria, tick encephalitis and other arthropod-borne diseases.

Beklemishev's outstanding book on the comparative anatomy of invertebrates, first published in 1944, saw a second edition in 1952 and was translated into many languages. His book on the ecology of $A$. maculipennis, published in 1948 , was equally suc. cessful. Beklemishev's main achievement was the thorough planning and organization of collective research on the bionomics of arthropod vectors of communicable diseases in the U.S.S.R. One of the results of this work was a recent book on seasonal changes in the biology of $A$. maculipennis over the whole vast territory of the U.S.S.R.- $a$ unique achievement in the field of entomological science. He also wrote a foreword to the monograph on age-grouping methods in Diptera of medical importance (prepared by one of his pupils, Dr. T. S. Detinova), which was recently published by the World Health Organization.

Beklemishev greatly increased our understanding of ecological and phenological factors in the distribution of malaria and introduced new notions of 'landscape malariology' as a basis for planning malaria control and eradication. The study of the physiology of malaria vectors led Beklemishev and his collaborators to the introduction of new methods of age-grading of female Anopheles. The importance of this in the epidemiological follow-up of malaria eradication was fully realized in the U.S.S.R. and is now increasingly appreciated in other parts of the world. The age-grading methods developed by the school created by Beklemishev are now being used for the study of the biology of house flies, tsetse flies, black flies and midges in other countries. Beklemishev's wide interests and keen intellect contributed greatly to the study of population biology of arthropods, to the study of the evaluation of parasitism in blood-sucking vectors of human and animal diseases, to the development of nosogeography of communicable diseases and to the analysis of general and specific aspects of natural foci of infection.

He was the author of a series of handbooks on medical ontomology and taught this subject to thousands of students at the Lomonosov University, at the Martsinovsky Institute and at the Central Postgraduate Medical School in Moscow. Beklemi- 